\title{
Outbreak of Novel Corona Virus in India: Lethal Pandemic
}

\section{Ankita Awasthi ${ }^{1 *}$ and Sangeeta Avasthi ${ }^{2}$}

${ }^{1}$ Assistant Professor, Zoology Department, A.N.D.N.N.M. Mahavidyalaya, Kanpur, Uttar Pradesh, India

${ }^{2}$ Associate Professor, Zoology Department, A.N.D.N.N.M. Mahavidyalaya, Kanpur, Uttar Pradesh, India

*Corresponding Author: Ankita Awasthi, Assistant Professor, Zoology Department, A.N.D.N.N.M. Mahavidyalaya, Kanpur, Uttar Pradesh, India.
Received: April 03, 2020

Published: April 29, 2020

(c) All rights are reserved by Ankita

Awasthi and Sangeeta Avasthi.
According to World Health Organization virus diseases still to emerge and represent a significant issue to public health. In December 2019, a pneumonia outbreak was reported in Wuhan, China. This outbreak was traced to a completely unique strain of coronavirus. COVID-19 is a communicable disease caused by a newly discovered corona virus. This new virus seems to be very contagious and has quickly spread globally. As of April 03, 2020, there have been a minimum of 52,869 confirmed death and quite $10,10,066$ confirmed cases within the corona virus pandemic. Lockdown, curfews, massive airport screening, quarantines and social distancing became the norms across the world. At an equivalent time, scientists round the world work tirelessly and knowledge about the transmission mechanism, the clinical spectrum of disease, new diagnostics and prevention and therapeutic strategies are rapidly developing.

Corona viruses are a family of viruses that range from the cold to MERS coronavirus, which is middle east respiratory syndrome corona virus, SARS, severe acute respiratory syndrome coronavirus and COVID-19, which causes lethal pandemic. Many coronaviruses are zoonotic (transmitted from animals to human) while SARS coronavirus is assumed to be an animal virus (transmitted from animal to animal) and first infected humans within the Guangdong province of southern China in 2002. The MERS coronavirus was passed on from dromedary camels to humans in Saudi Arabia in 2012. SARS-CoV-2 virus transmitted from bat to humans.

It is a single stranded RNA virus. SARS-Cov-2 virus particles are spherical and have mushroom shaped protein called spikes protruding from their surface, giving the particle a crown like appearance. The spikes bind to the human cells and allowing virus to gain entry. The spike protein of novel corona virus shares $98 \%$ sequence identity with the spike protein of bat coronavirus. The researchers found that spike protein of SARS-CoV-2 binds to the cellular receptor called Angiotensin converting enzyme 2, which is entry point into human cells. It has 10 to 20 -fold higher binding affinity then SARS. The higher binding affinity causes higher human to human transmission.

Most people infected with the COVID-19 virus will experience mild to moderate respiratory illness and recover without requiring special treatment. The latter includes severe pneumonia. Acute respiratory distress syndrome, sepsis and septic shock. Older people and people with underlying medical issues like cardiovascular disease, diabetes, chronic respiratory illness and cancer are more likely to develop serious illness. Main symptoms are fever, dry cough, dyspnea, diarrhea and pharyngitis. The COVID-19 virus spreads primarily through droplets of saliva or discharge from the nose when an infected person coughs or sneezes, so it's important that you simply also practice respiratory etiquette. If an individual touch a surface or object that has been infected by virus and then touches his nose, mouth or eyes, he may get infected. Primarily research indicates that the virus may remain viable on plastic and steel for up to three days but does not survive on cardboard for more than one day or on cooper for more than four hours and is inactivated by soap.

There are 2547 confirmed COVID-19 cases in India till 3 April. 162 get recovered while 62 deaths are recorded.

The virus is often detected employing a RT-PCR test. In India, the government facilities to check for the virus include many labs belonging to the Viral research and Diagnostic laboratories network of the Indian council of medical research labs under the national center for disease control and NIV. Mylab discovery become the first firm in India to get full approval to make and sell testing kit. Each Mylab kit can test 100 samples and price 1200 Rs that's a few

\begin{tabular}{|c|c|}
\hline Date & Total corona virus cases \\
\hline 15 February & 3 \\
\hline 20 February & 3 \\
\hline 25 February & 3 \\
\hline 1 March & 6 \\
\hline 5 March & 30 \\
\hline 10 March & 62 \\
\hline 15 March & 114 \\
\hline 20 March & 249 \\
\hline 25 March & 657 \\
\hline 27 March & 727 \\
\hline 30 March & 1171 \\
\hline 1 April & 1998 \\
\hline 3 April & 2547 \\
\hline
\end{tabular}

Table 1 


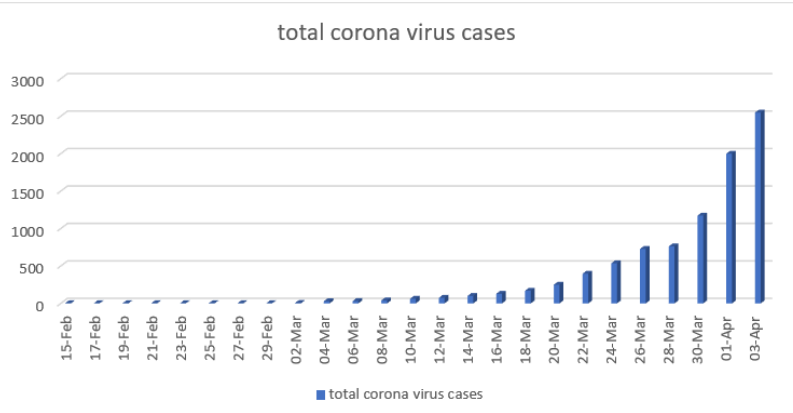

Figure 1

\begin{tabular}{|l|c|}
\hline \multicolumn{1}{|c|}{ State } & Cases (Till 30-03-2020) \\
\hline Maharashtra & 320 \\
\hline Kerala & 237 \\
\hline Karnataka & 110 \\
\hline Telangana & 129 \\
\hline Uttar Pradesh & 172 \\
\hline Delhi & 384 \\
\hline Gujrat & 95 \\
\hline Rajasthan & 133 \\
\hline Tamil Nadu & 411 \\
\hline Punjab & 46 \\
\hline Haryana & 43 \\
\hline Jammu and Kashmir & 49 \\
\hline Madhya Pradesh & 98 \\
\hline Andhra Pradesh & 149 \\
\hline West Bengal & 53 \\
\hline Ladakh & 13 \\
\hline Bihar & 29 \\
\hline Andaman and Nicobar island & 10 \\
\hline Chandigarh & 18 \\
\hline Chhattisgarh & 9 \\
\hline Uttarakhand & 10 \\
\hline Goa & 6 \\
\hline Himachal Pradesh & 3 \\
\hline Odisha & 5 \\
\hline Puducherry & 4 \\
\hline Mizoram & 2 \\
\hline Manipur & 1 \\
\hline Assam & 3 \\
\hline Arunachal Pradesh & 1 \\
\hline & \\
\hline & \\
\hline
\end{tabular}

Table 2

quarter of the 4500 Rs that Indian pays to import Covid-19 testing kits from abroad. This kit gives the diagnosis in two and a half hours while the imported testing kit takes six-seven hours.

At this point there is no specific vaccine or treatment for COVID-19. however, there are many ongoing clinical trials evaluating potential treatments. The best way to prevent and hamper transmission is be informed about the COVID-19 virus, the disease it causes and the way it spreads. Protect yourself and others from infection by washing your hands or using an alcohol based- rub frequently and not touching your face. Social distancing and isolation or quarantine are the best way to prevent the infection.

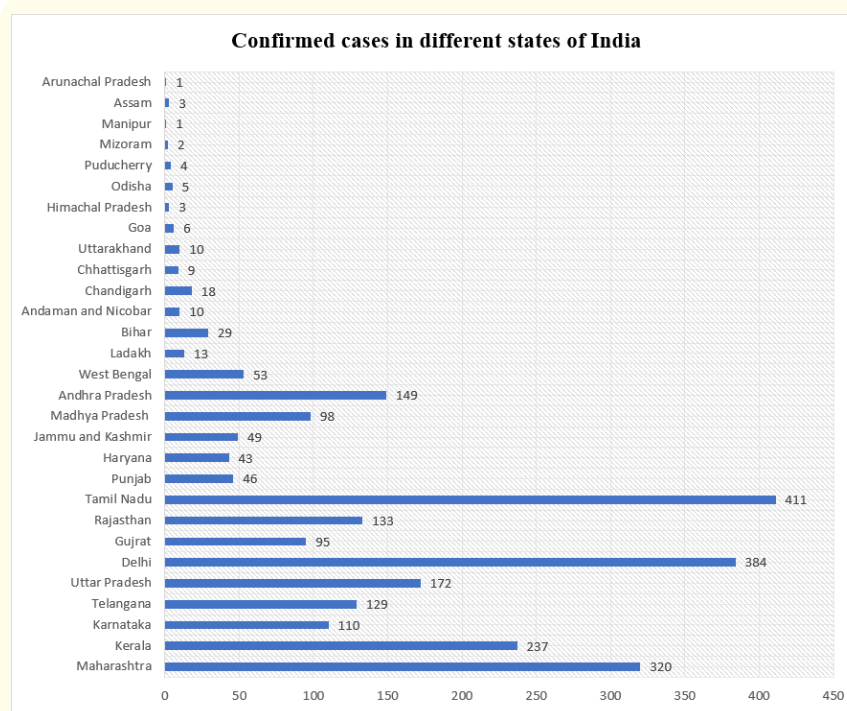

Figure 2

Assets from publication with us

- Prompt Acknowledgement after receiving the article

- Thorough Double blinded peer review

- Rapid Publication

- Issue of Publication Certificate

- High visibility of your Published work

Website: www.actascientific.com/

Submit Article: www.actascientific.com/submission.php Email us: editor@actascientific.com

Contact us: +91 9182824667 